\title{
COMPARISON OF THE LOWER EXTREMITIES' EXPLOSIVE MUSCULAR STRENGTH VIA JUMPING TESTS IN DIFFERENT PERFORMANCE LEVEL AND AGE GROUPS OF WOMEN VOLLEYBALL PLAYERS
}

\author{
Zlatava Jakubšová, František Vaverka*, Daniel Jandačka*
}

\author{
Technical University of Ostrava, Ostrava, Czech Republic \\ *Human Motion Diagnostic Center, University of Ostrava, Ostrava, Czech Republic
}

Submitted in June, 2010

BACKGROUND: Sport performance in volleyball is significantly influenced by the quality of the player's jumping abilities, above all on the height of the jump. Results in jumping tests indirectly indicate information about explosive muscle strength. Information about the quality of the results of jumping tests is the starting point for the monitoring of the athlete's conditioning.

OBJECTIVE: This work's purpose consists in finding out whether there exist some differences between women volleyball players according to their age and their sport performance level and whether women volleyball players differ from women university students. A secondary aim of the study is to assess the suitability of using three jumping tests in volleyball.

METHODS: For the set of women volleyball players $(n=273)$ divided into five different age and sport performance categories and for the set of university female students $(n=33)$, three jump tests were applied - the spike jump test SPJ, the counter movement jump test CMJ and the standing broad jump test SBJ. Statistical analysis was done using the Czech STATISTICA system, version 6 (Kolmogorov-Smirnov test, Spearman coefficient correlation, paired t-test and ANOVA for independent samples).

RESULTS: Relatively small and mostly statistically insignificant differences have been found between women volleyball players of various age and sport performance groups. All groups of volleyball players significantly exceeded the university students set in the level of their explosive muscle strength. Our research showed a lower level of jump performance, especially in what concerns the highest sport performance of women players. The initial hypotheses about the usefulness of applying three jumping tests in volleyball were confirmed.

CONCLUSIONS: The differences in the results of jumping tests for different age and sport performance groups of women volleyball players are small. The relatively lower level of the jumping abilities of the highest sport performance players was discovered. Experience with applying three jumping tests have shown their convenience to be utilizable in volleyball. Each test has its own specificity to provide information about the quality of jumping abilities with regards to the sport performance level and to the age of the tested female players.

Keywords: Jumping abilities, testing, counter movement jump, spike jump, volleyball, women.

\section{INTRODUCTION}

Concerning current volleyball playing performance, increasing dynamicity, speed and agility within the female players' movement actions is characteristic (Baacke, 1994; Papageorgiou, 1999; Buchtel et al., 2005). Sporting performance is significantly influenced by the offensive phase quality, depending above all on the jump height. Lehnert, Novosad, and Orlová (1993) characterize volleyball performance as a multi-factorial effect with a significant representation of the take-off ability factor, which influences, within a great range, the offensive phase quality as well as the blocker's defense activities.

In practice, there are different variants of tests utilized in volleyball, whose selection is given by the char- acteristic of the movement activities which are typical for volleyball (Kaplan, 1997; Papageorgiou \& Spitzley, 2002; Přidal \& Zapletalová, 2003). Current volleyball is characterized by a great quantity of jumps, skips, hops and other kinds of take off (Abendroth-Smith \& Kras, 1999). In volleyball practice, we can divide take offs into two basic skills - the spike jump (from one leg, from both legs) and block jump (from one place, after movement). To ensure the lower extremities explosive muscle strength and also to evaluate the techniques of execution of the spike jump in volleyball, it is convenient to use a counter movement jump after a three to five step run up which has been called the spike jump test (SPJ). The SPJ test evaluates the volleyball player's special jumping knowledge, which is practically identical to the take off execution during a match. The spike jump test is a mat- 
ter of interest for many authors who approach its examination in order to improve volleyball players' jumping performance and, simultaneously, they consider it to be an efficient checking means to find out explosive muscle strength level (Bobbert, Huijing, \& Van Ingen Schenau, 1987; Coleman, Benham, \& Northcott, 1993; Forthomme, Crossier, Ciccarone, Crielaard, \& Cloes, 2005; Tillman, Haas, Brunt, \& Benett, 2004; Tokuyama, Ohashi, Iwamoto, Takaoka, \& Okubo, 2005).

Aside from the specific volleyball SPJ test, one mostly comes across the general take off abilities tests as, for example, the standing broad jump or the counter movement jump (Měkota \& Blahuš, 1983; Měkota $\&$ Novosad, 2007). Counter movement jumps are often utilized as an easy test to check anaerobic muscle strength development (Komi \& Bosco, 1978; and others). In practice, we meet different variants of counter movement jumps according to the sports specialization of the monitored sports groups. The most used is the counter movement jump (CMJ) which is executed with a movement of the arm or with its exclusion. A specific variant consists in the counter movement jump from a static lowered position (squat jump) which is used, for example, in ski jumpers testing. The counter movement jump is evaluated by this test with high reliability and validity (Měkota \& Blahuš, 1983; Vaverka, 2000; and others) and it makes possible explosive muscle strength comparison between different groups of persons.

Obtaining final information concerning the results of the counter movement jump test (jump height) is not an easy thing. Aside from the imprecise Sargent jump (Sargent, 1921), the more complex systems of jump height measuring are based on calculations of the flight phase or with the help of the kinetic analysis of the reaction force measured (Vaverka, 2000). The counter movement jump kinetics analysis resulting from the dynamometrically measured reaction force enables us, besides determining the final characteristics of the achieved jump height, to obtain a great number of other information about the force, speed and race track course of the centre of gravity of an individual (Vaverka, Salinger, \& Novosad, 1979; Vaverka, 2000). Detailed information concerning the jump results obtained by the calculation of the flight duration or on the basis of kinetic analysis requires specific measuring and calculation systems and the testing is usually dependent upon specific laboratory conditions.

The results of the men and women volleyball players' take off abilities testing bring us important information for improving training quality (Beal \& Elder, 1988; Boyle, 2004; Ejem, 1993, 1998). The standing broad jump is utilized to evaluate youth and beginners' jumping talents. The counter movement jump as well as the standing broad jump are made an integral part of the group of tests which are utilized within the framework of the diagnostics of the representation of the selection of players' test batteries, at youth tournaments and at sports clubs (Ejem, 1998). Lehnert and Zháněl (2009) proposed a testing set of motoric tests in volleyball which comprises groups of tests for senior and youth representation, youth centers, sports secondary schools and selected pupils at primary schools. In volleyball, special tests are utilized, whose content comprises identical movements to the movements used in the game. It consists in special movement abilities tests (Bartlett, 1985; Bartlett, Smith, Davis, \& Peel, 1991; Colins \& Hodges, 2001).

In scientific publications, we can meet with take off abilities testing, especially for top level players. There are also a lot of studies on men (Bobbert, Huijing, \& Van Ingen Schenau, 1987; Coleman, Benham, \& Northcott, 1993; Forthomme et al., 2005; Tokuyama et al., 2005; Dowling \& Vamos, 1993; Vint \& Hinrich, 1996; Smith, Roberts, \& Watson, 1992; Newton, Kraemer, \& Hakkinen, 1999) in comparison to the less numerous studies on women (Tillman et al., 2004; Lehnert, Novosad, \& Orlová, 1993; Voight \& Vetter, 2003; Hsieh \& Heise, 2008). So far, a minimal interest has been dedicated to the lower extremities explosive muscle strength level monitoring for youth and lower performance level players (Ejem, 1993; Haník \& Lehnert, 2004; Lehnert, Lamrová, \& Elfmark, 2009).

The purpose of this work consists in comparing the explosive take off strength level by means of motoric tests among women volleyball players of different age and sport performance categories as compared to a set of university female students. We are interested in finding out whether there exist any differences in their explosive muscle strength related to the age and the sport performance of these women players and whether the women volleyball players differ from the population of recreational sportswomen. We suppose that as the age and sport performance of women volleyball players' increases, the explosive muscle power will also significantly rise. Another purpose of this study consists in comparison of the different variants of the tests and to determine their usefulness under different conditions of testing in volleyball.

\section{METHOD}

Five sets of women volleyball players $(n=273)$ and one set of recreational sport practicing university female students $(n=33)$ participated in this research. In TABLE 1 are presented the basic characteristics of the tested persons according to their number, age and body sizes. The monitored groups were teams of women players of different age categories and the control group consisted in recreational women volleyball 
players, female students of the first year at the Technical University of Ostrava. The measuring was done within the period 2003-2005 at the Human Movement Diagnostics Center of the University of Ostrava and in the sports hall of the University Sports Club of the Technical University of Ostrava and this, always within the period from October-November to the end of the training cycle preparation phase.

Three tests were selected to evaluate explosive muscle strength level: the SPJ - spike jump test, the CMJ counter movement jump, SBJ - standing broad jump. The spike jump test is a typical volleyball element where, after a three step run up, the player takes off vertically with the accompanying arm movement. The counter movement jump is a standardized take off with counter movement and accompanying arm movement (Vaverka, 2000). The standing broad jump is a classical motoric test (Měkota \& Blahuš, 1983). The testing was done according to the principles mentioned in the literature (Měkota \& Blahuš, 1983).

To evaluate the results of the SPJ and CMJ tests, the professional system called FITRO Jumper II (manufactured by FITRONIC, s.r. o., Bratislava) was utilized. The jump evaluation results from the measuring by the described system is based on the measurement of the support and non-support phases of the jump. The system provides a great number of variables characterizing the counter movement jump, among which the following ones have been selected for the purpose of this study HJ - jump height $(\mathrm{cm}), \mathrm{P}$ - power within the take off active phase (W) and P' - average power computed in the whole jumping cycle $(\mathrm{W} / \mathrm{kg})$.

The measuring of all of these three tests was always done in one single day. Prior to each test, the measuring women participants warmed up and performed effectuated training in the course of which the jump execution technique was explained to them and corrected. Prior to the beginning of each test, the female participants also had to successfully perform three training jumps. Between each individual test, the time interval was two minutes for each participant. In each test, three succeeding attempts were recorded and the final result was the best jump from the height point of view.

For the statistical analysis, the following tests were selected - a test of experimental data distribution (Kolmogorov-Smirnov), the paired t-test, the Spearman rank correlation coefficient ation and the ANOVA (Scheffé post-hoc test). All of the calculations were done in the program called STATISTICA $C z$, version 6 by StatSoft, Inc. (2001).

\section{RESULTS}

\section{Differences between the selected groups}

From the jump height and from the point of view of the statistical structure of the important differences between the groups, we can see a similar picture for each variant of the tests (TABLE 2). In all of the three tests, the checked set of female students reaches lower values of jump height and length in what concerns the standing broad jump than the other women volleyball players group. The differences between the female students and the women volleyball players are statistically significant (except for the counter movement jump at U15). In the test results, the differences between the sets of women volleyball players are relatively small and in many cases, they remain statistically insignificant.

With a general view to the structure of the statistically significant differences between the groups, the spike jump test differs from two classical tests concerning counter movement jumps and the standing broad jump. Concerning the spike jump test, we can find differences between U15 and all of the other groups and in what concerns the classical tests, the number of significant differences between the women players' groups decreases. It is interesting to notice that the differences between women - national top level or other groups of women volleyball players, are not statistically significant in the SPJ test. On the other hand, within the framework

TABLE 1

Selected sets of volleyball players - women, basic information

\begin{tabular}{|l|c|c|c|c|c|c|c|c|c|}
\hline \multirow{2}{*}{ Set } & \multirow{2}{*}{ Number } & \multicolumn{2}{|c|}{ Age (years) } & \multicolumn{2}{c|}{ Body height (m) } & \multicolumn{2}{c|}{ Body weight (kg) } & \multicolumn{2}{c|}{ Body Mass Index } \\
\cline { 3 - 10 } & & Mean & SD & Mean & SD & Mean & SD & Mean & SD \\
\hline U15 & 50 & 13.50 & 0.70 & 1.71 & 0.06. & 56.10 & 6.50 & 19.11 & 1.69 \\
\hline U16 & 57 & 15.20 & 0.50 & 1.75 & 0.06 & 63.00 & 7.40 & 20.50 & 2.00 \\
\hline U18 & 49 & 17.10 & 0.80 & 1.80 & 0.04 & 67.70 & 6.50 & 20.96 & 1.63 \\
\hline WNAL & 91 & 24.20 & 5.30 & 1.75 & 0.05 & 66.80 & 7.10 & 21.74 & 2.07 \\
\hline WNTL & 26 & 20.40 & 3.00 & 1.79 & 0.05 & 67.20 & 7.20 & 21.00 & 1.64 \\
\hline WREL & 33 & 19.90 & 1.40 & 1.68 & 0.05 & 61.00 & 6.00 & 21.62 & 1.62 \\
\hline
\end{tabular}

Legend: U15, U16, U18 - sets of women volleyball players under 15, 16, 18 years of age; WNAL - women volleyball players, national level; WNTL - women volleyball players, national top level; WREL - women volleyball players, recreational level 
of the CMJ and SBJ general motoric tests, the national top level women players differ more in comparison to the other groups in jump height and length.

The complex comparison of the differences between the sets in each individual test is shown in graphical illustration (Fig. 1a). The curves expressing the greatness of the jump height and length in all of the three tests are practically the same from the point of view of their course. Having identical models in the tests results in graphical illustration for the different groups of tested women players, evidencing the fact that all of the three tests provide almost the same information concerning the explosive muscular strength level.

\section{Test comparison from the power point of view}

The term "power" $(\mathrm{P})$ is defined using the physical value called a "watt" (W) and it differs from the traditional terms used to describe performance in the sense of the result of a sports activity. The results illustrate that the differences in the $\mathrm{P}$ performance greatness between the different tested groups have a similar trend in both cases of vertical jumps (Fig. 1b). The relative performance $\mathrm{P}$ ' analysis $(\mathrm{W} / \mathrm{kg}$ ) brought us practically identical information about the differences between the selected groups compared to those we can find in the $P$ value. When we compare the trends of the curves expressing the tests results of each individual group and the P performance curves (Fig. 1), we can see a high range of similarity. The statistical significance of the differences between the performance values is similar to the differences in testing between the results of the three tests. The mentioned facts illustrate that, in order to quantify the level of explosive muscle strength, only test results expressed in jump height or length provide a sufficient and quality indicator.

TABLE 2

Results of three tests of jumping and test of differences among selected sets

\begin{tabular}{|c|l|c|c|c|c|c|c|c|c|c|c|}
\hline \multicolumn{10}{|c|}{ Spike jump test (SPJ) } \\
\hline Rank & Set & \multicolumn{3}{|c|}{ Height of jump (cm) } & \multicolumn{5}{c|}{ Statistical significance of differences } \\
\hline & & Mean & SD & min. & max. & 1 & 2 & 3 & 4 & 5 & 6 \\
\hline 1. & U15 & 36.64 & 6.44 & 26.7 & 52.1 & & & & & & \\
\hline 2. & U16 & 38.33 & 5.33 & 29.2 & 50.1 & $*$ & & & & & \\
\hline 3. & U18 & 38.59 & 6.80 & 26.9 & 63.8 & $*$ & & & & & \\
\hline 4. & WNAL & 40.03 & 5.77 & 26.7 & 53.9 & $*$ & & & & & \\
\hline 5. & WNTL & 43.12 & 5.40 & 34.6 & 54.7 & $*$ & $*$ & & & & \\
\hline 6. & WREL & 31.00 & 5.72 & 19.4 & 41.7 & $*$ & $*$ & $*$ & $*$ & $*$ & $*$ \\
\hline
\end{tabular}

\begin{tabular}{|c|l|c|c|c|c|c|c|c|c|c|c|}
\hline \multicolumn{10}{|c|}{ Counter movement jump (CMJ) } \\
\hline Rank & Set & \multicolumn{3}{|c|}{ Height of jump (cm) } & \multicolumn{5}{c|}{ Statistical significance of differences } \\
\hline & & Mean & SD & min. & max. & 1 & 2 & 3 & 4 & 5 & 6 \\
\hline 1. & U15 & 30.76 & 4.62 & 19.7 & 44.4 & & & & & & \\
\hline 2. & U16 & 33.25 & 4.72 & 25.6 & 45.0 & & & & & & \\
\hline 3. & U18 & 33.13 & 4.88 & 22.8 & 43.0 & & & & & & \\
\hline 4. & WNAL & 34.80 & 4.93 & 23.5 & 47.6 & $*$ & & & & & \\
\hline 5. & WNTL & 37.52 & 5.37 & 30.3 & 50.1 & $*$ & $*$ & $*$ & & & \\
\hline 6. & WREL & 28.07 & 4.66 & 18.5 & 38.6 & & $*$ & $*$ & $*$ & $*$ & \\
\hline
\end{tabular}

\begin{tabular}{|c|l|c|c|c|c|c|c|c|c|c|c|}
\hline \multicolumn{10}{|c|}{ Standing broad jump (SBJ) } \\
\hline Rank & Set & \multicolumn{3}{|c|}{ Length of jump (cm) } & \multicolumn{5}{c|}{ Statistical significance of differences } \\
\hline & & Mean & SD & min. & max. & 1 & 2 & 3 & 4 & 5 & 6 \\
\hline 1. & U15 & 197.86 & 16.19 & 158 & 227 & & & & & & \\
\hline 2. & U16 & 203.51 & 16.17 & 164 & 244 & & & & & & \\
\hline 3. & U18 & 204.67 & 14.30 & 179 & 245 & & & & & & \\
\hline 4. & WNAL & 207.21 & 14.27 & 177 & 237 & $*$ & & & & & \\
\hline 5. & WNTL & 220.42 & 15.61 & 182 & 255 & $*$ & $*$ & $*$ & $*$ & & \\
\hline 6. & WREL & 174.09 & 19.31 & 140 & 208 & $*$ & $*$ & $*$ & $*$ & $*$ & \\
\hline
\end{tabular}

Legend: U15, U16, U18 - sets of women volleyball players under 15, 16, 18 years of age; WNAL - women volleyball players, national level; WNTL - women volleyball players, national top level; WREL - women volleyball players, recreational level; ${ }^{*} \mathrm{p}<0.05 ;{ }^{* *} \mathrm{p}<0.01$ 


\section{Difference between the spike jump test and the counter movement jump}

The difference between both variants of SPJ and CMJ jumps is statistically significant for all of the sets (women volleyball players $\mathrm{p}<0.01$, female students $\mathrm{p}<0.05$ ) and in all cases, the SPJ height is higher than the CMJ height (TABLE 3). The gain amplitude in the jump height for the SPJ, expressed in percentage of $\mathrm{CMJ}$, is within the range of $15-19 \%$ for volleyball players and amounts to $10 \%$ only for the female students. The results proved that the connection of the run up with the take off increases the jump height from $15 \%$ to $20 \%$ of their basic performance in CMJ.

\section{DISCUSSION}

Between the groups of women volleyball players (except for the U15), there are very small and statistically insignificant differences in the jump height. National top level players reach the best performances in all of the tests and they differ from other groups in CMJ and SBJ classical motoric tests only. Tillman, Hass, Brunt, and Bennett (2004) mention that, in what concerns top women volleyball players, the technique of jump execution has an influence on the jump height. With regards to the Hsieh and Heise (2008) studies results, they affirm that top level women volleyball players should reach better results in jump height. It seems that concerning the group of the tested national top level players, the take off quality is not so high. The participation of the players in the Czech national top level competition is certainly influenced by other qualities (physical proportion, technique, playing experience, etc.) and suitable attention is not given to the take off level. The similar results of the tests for national top level women players and U18 players are certainly the consequence of the state of affairs in which a lot of young and promising U18 players

Fig. 1

Graphical expression of test results (A - height and length of jump, B - power P)

A

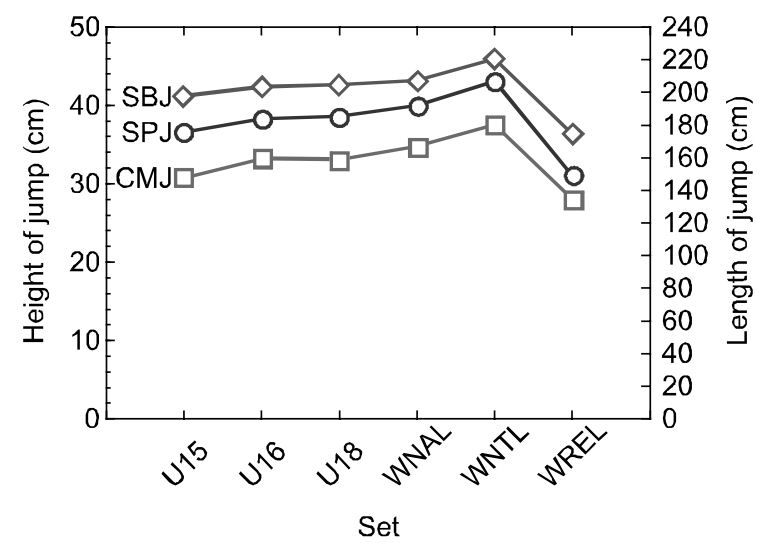

B

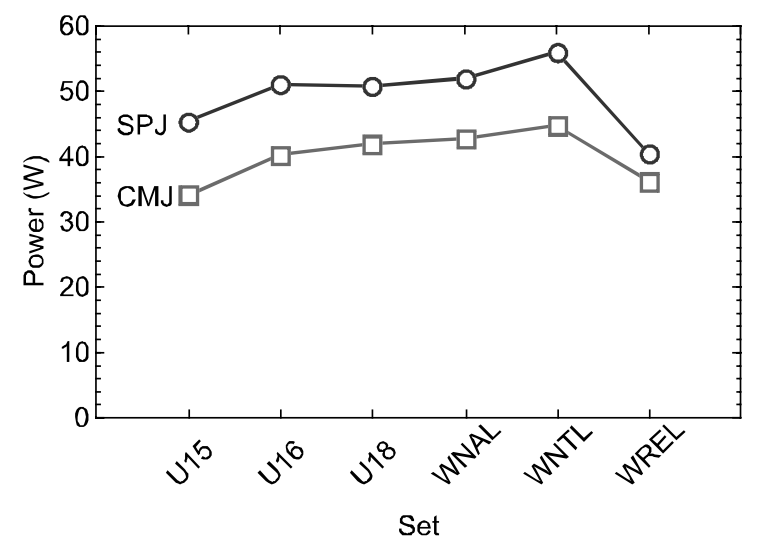

Legend: U15, U16, U18 - sets of women volleyball players under 15, 16, 18 years of age; WNAL - women volleyball players, national level; WNTL - women volleyball players, national top level; WREL - women volleyball players, recreational level; SPJ - spike jump test; CMJ - counter movement jump; SBJ - standing broad jump

TABLE 3

Differences between spike jump test (SPJ) and counter movement jump (CMJ)

\begin{tabular}{|c|c|c|c|c|c|c|c|c|}
\hline \multirow{3}{*}{ Set } & \multicolumn{5}{|c|}{ Height of jump (cm) } & \multirow{2}{*}{\multicolumn{2}{|c|}{ t-test for paired samples }} & \multirow{3}{*}{$\begin{array}{c}\text { SPJ } \\
\text { expressed } \\
\text { in percent } \\
\text { of } \mathrm{CMJ}(\%) \\
\end{array}$} \\
\hline & \multicolumn{2}{|c|}{ SPJ } & \multicolumn{2}{|c|}{ CMJ } & \multirow{2}{*}{$|\mathbf{d}|$} & & & \\
\hline & Mean & SD & Mean & SD & & $\mathbf{t}$ & $\mathbf{p}$ & \\
\hline U15 & 36.64 & 6.44 & 30.76 & 4.62 & 5.88 & 10.039 & $* *$ & 119 \\
\hline U16 & 38.33 & 5.33 & 33.25 & 4.72 & 5.08 & 14.499 & $* *$ & 115 \\
\hline U18 & 38.59 & 6.80 & 33.13 & 4.88 & 5.46 & 8.168 & $* *$ & 116 \\
\hline WNAL & 40.03 & 5.77 & 34.80 & 4.93 & 5.23 & 16.498 & $* *$ & 115 \\
\hline WNTL & 43.12 & 5.40 & 37.52 & 5.37 & 5.60 & 3.180 & $* *$ & 115 \\
\hline WREL & 31.00 & 5.72 & 28.07 & 4.66 & 2.93 & 2.750 & $*$ & 110 \\
\hline
\end{tabular}

Legend: U15, U16, U18 - sets of women volleyball players under 15, 16, 18 years of age; WNAL - women volleyball players, national level; WNTL - women volleyball players, national top level; WREL - women volleyball players, recreational level; ${ }^{*} \mathrm{p}<0.05 ;{ }^{* *} \mathrm{p}<0.01$ 
regularly participate in the championship matches of national top level competition. At the present time, the Czech highest level volleyball competition is composed, for a high percentage of it, of junior aged players (U18). However, we could expect that highly intensive training preparation in the women's top national level competition would bring greater differences between top level players and lower level performing players in volleyball.

Differences between women volleyball players and women players at the recreational level in what concerns explosive muscle strength level are naturally significant and expected. The question we can ask ourselves is whether a difference within a range of 7 to $12 \mathrm{~cm}$ for the SPJ test and of 2 to $9 \mathrm{~cm}$ for the CMJ between the systematically trained volleyball players and the players at recreational level is sufficient. If we compare the results of our studies with the data published in the literature (Lehnert, Novosad, \& Orlová, 1993; Voight $\&$ Vetter, 2003) we can see that the tested players of the Czech top level competition reach a lower level in what concerns explosive muscle strength than the world top level players. During World championship junior teams testing, Lehnert, Novosad, and Orlová (1993) mention a counter movement jump average height of $41 \mathrm{~cm}$ and of $47 \mathrm{~cm}$ for the spike jump test. If we express the top national level women players' measured values in percentages of the best worldwide junior players' jump height (jump height $=100 \%$ ), then the tested top national level women players reach the value of $92 \%$ for the spike jump test and of $90 \%$ for the counter movement jump. The mentioned confrontation with the data obtained at the world level junior teams shows some lack in explosive muscle strength at the level of the tested highest Czech national competition players.

Different complications of counter movement jump analyses enable us to obtain a great quantity of numbers and other information and this not only concerning the jump height but also regarding the time, force and track structure of the given movement (Vaverka, 2000). The method utilized in this study has provided information about the performances $\mathrm{P}$ and $\mathrm{P}^{\prime}$ in the case of a given jump. The confrontation of the $\mathrm{P}$ and $\mathrm{P}$ ' performance size in the cases of SPJ and CMJ tested jumps made us realize that the differences between the tested sets in these values have the same character as the differences in the jump height (Fig. 1). This fact is understandable, because the volleyball women players' physical structure is very similar and their performance greatness while jumping depends especially, when body proportions are at a standard level, on the height reached during the jump. From the practical point of view, if the experimenter does not solve any specific problems, finding out the jump height appears to be sufficient to determine the level of the lower extremities' explosive muscle strength.

The differences in the jump height which we found while comparing two variants of SPJ and CMJ jumps were significant for all of the tested sets. The SPJ jump height is $5.2-5.9 \mathrm{~cm}(115-119 \%)$ higher for women volleyball players and $2.2 \mathrm{~cm}(110 \%)$ for the female students than the CMJ height (100\%) is. These differences show that the connection of run up and take off increases the jump height. The above mentioned fact is confirmed by numerous literature sources (Shahbazi, Mirabedi, \& Gaeini, 2007). Lehnert, Novosad, and Orlová (1993) describe the spike jump as a test evaluating the volleyball players' special jumping abilities. The studies' results showed that there were smaller differences in the SPJ test values between the performing groups of players than between the results of the CMJ and SBJ classical test. It seems that the SPJ test execution technique probably reduces the differences between various women volleyball playing groups.

The basic problem of the diagnostics of those two variants of counter movement jumps consists in technical limits requiring complicated technology. Their application is mostly possible under laboratory conditions. The studies' results proved the utility of the information obtained from the standing broad jump classical test. Because of its simplicity and great measuring precision, the SBJ test appears to be a suitable diagnostics instrument which can be especially utilized in beginners and youth in order to find out their level of talent for jumping and also to check the effectiveness of training for the whole performing spectrum of women volleyball players.

\section{CONCLUSION}

Women volleyball players significantly differ from the recreationally sporting women population in their explosive muscle strength level. Concerning height in the spike jump test, the differences are relatively small and mostly statistically insignificant between the different sport performance levels of women volleyball players. Regarding the counter movement jump, national top level players reach a higher jump height than the youth categories and concerning the standing broad jump they also differ from all the rest of the monitored groups. The studies' results show that the national top level players and national level players have not reached the expected differences in their lower extremities' explosive muscle strength. The height of the jump and the variable power (P) derived from the measured result of the jump provide similar information about the quality of the jump.

Experience with the testing of the standing broad jump shows that it is a quality and easily done test for basic orientation in the jumping abilities level of players. Its utilization is especially suitable at the training practice level for youth and talented players' selection. To diagnose the women volleyball players' jumping level, it is suitable to use the counter movement jump and the 
spike jump test. These studies proved that the connection of the run up in the spike jump test increases the jump height by $15-20 \%$ of the counter movement jump height. With regards to the relatively small differences in the jump height between the individuals in the CMJ, we recommend the utilization of exact measuring procedures requiring collaboration with specialized biomechanical laboratories (using Kistler or similar systems).

\section{ACKNOWLEDGEMENT}

This research was supported by the grant of the Czech Science Foundation No. 406/08/0572.

\section{REFERENCES}

Abendroth-Smith, J., \& Kras, J. (1999). The volleyball spike. Journal of Physical Education, Recreation and Dance, 70(3), 56-59.

Baacke, H. (1994). The particular features of volleyball and consequences for training. International Volleyball Technology, 2, 9-20.

Bartlett, J. F. (1985). A simplified volleyball skills test for beginning level instruction. Journal of Physical Education, Recreation and Dance, 56, 20-21.

Bartlett, J., Smith, L., Davis, K., \& Peel, J. (1991). Development of valid volleyball skills test battery. Journal of Physical Education and Dance, 62, 19-21.

Beal, D., \& Elder, B. (1988). Power jumping: The Olympic gold medal approach to jump training. Columbus, $\mathrm{OH}$ : Sports Imports.

Bobbert, M. F., Huijing, P. A., \& Van Ingen Schenau, G. J. (1987). Drop jumping. I. The influence of jumping technique on the biomechanics of jumping. Medicine and Science in Sports and Exercise, 19(4), 332-338.

Boyle, M. (2004). Functional training for sports. Champaign, IL: Human Kinetics.

Buchtel, J. et al. (2005). Teorie a didaktika volejbalu. Praha: Karolinum.

Coleman, S., Benham, A., \& Northcott, S. (1993). A three dimensional cinematographical analysis of the volleyball spike. Journal of Sports Sciences, 11, 259-302.

Colins, D. R., \& Hodges, P. B. (2001). A comprehensive guide to sports skills tests and measurement (2nd ed.). Lanham: The Scarecrow Press.

Dowling, J., \& Vamos, L. (1993). Identification of kinetic and temporal factors related to vertical jump performance. Journal of Applied Biomechanics, 9, 95-110.

Ejem, M. (1993). Motorické testy pro ZŠ a základní výběr [Metodický dopis]. Praha: Sportpropag.
Ejem, M. (1998). K použití motorických testů ve volejbalu. Zpravodaj Českého volejbalového svazu, 6, 13-14, 19-20.

Forthomme, B., Croisier, J. L., Ciccarone, G., Crielaard, J. M., \& Cloes, M. (2005). Factors correlated with volleyball spike velocity. American Journal of Sports Medicine, 33, 1513-1519.

Haník, Z., Lehnert, M. a kol. (2004). Volejbal 1: herní dovednosti v tréninku mládeže. Praha: Český volejbalový svaz.

Hsieh, C. H., \& Heise, G. D. (2008). Arm swing of volleyball jump performance between advanced and recreational female players [Abstract]. Retrieved 20. 12. 2009 from the World Wide Web: www.asbweb.org/conferences/2008/abstracts/306

Kaplan, O. (1997). Přenos vědních poznatků do tréninku volejbalu. In P. Tilinger \& T. Perič (Eds.), Sborník referátů z národní konference Tělesná výchova a sport na prelomu století (pp. 235-237). Praha: FTVS UK.

Komi, P. V., \& Bosco, C. (1978). Utilization of stored elastic energy in leg extensor muscles by men and women. Medicine and Science in Sports, 10(4), 261-265.

Lehnert, M., Lamrová, I., \& Elfmark, M. (2009). Změny rychlostně-silových předpokladů volejbalistek v průběhu a po absolvování plyometrického tréninkového programu. Acta Universitatis Palackinae Olomoucensis. Gymnica, 38(1), 59-66.

Lehnert, M., Novosad, J., \& Orlová, A. (1993). Příspěvek k hodnocení odrazových schopností vrcholových volejbalistek. Acta Universitatis Palackinae Olomoucensis. Gymnica, 22, 93-102.

Lehnert, M., \& Zháněl, J. (2009). Nově navržené motorické testy ve volejbale. Zpravodaj Českého volejbalového svazu, 2, 17-28.

Měkota, K., \& Blahuš, P. (1983). Motorické testy v tělesné výchově. Praha: Státní pedagogické nakladatelství.

Měkota, K., \& Novosad, J. (2007). Motorické schopnosti. Olomouc: Univerzita Palackého.

Newton, R. U., Kraemer, W. J., \& Hakkinen, K. (1999). Effects of ballistic training on pre-season preparation of elite volleyball players. Medicine and Science in Sports and Exercise, 31, 323-330.

Papageorgiou, A. (1999). Training with the new rules. The Coach, 1, 13.

Papageorgiou, A., \& Spitzley, W. (2002). Volleyball: $A$ handbook for coaches and players. Oxford: Meyer $\&$ Meyer Sport.

Přidal, V., \& Zapletalová, L. (2003). Volejbal - herný výkon, tréning, riadenie. Bratislava: PEEM.

Sargent, D. A. (1921). The physical test of man. American Physical Education Review, 26, 188-194.

Shahbazi, M. M., Mirabedi, A., \& Gaeini, A. A. (2007). The volleyball approach: An exploration of run up last stride length with height and deviation in land- 
ing. In Proceeding of XXV International Symposium of Biomechanics and Sports (pp. 574-577). Ouro Preto: ISBS.

Smith, D. J., Roberts, D., \& Watson, B. (1992). Physical, physiological and performance differences between Canadian national team and universiade volleyball players. Journal of Sports Sciences, 10, 131-138.

Tillman, M. D., Hass, C. J., Brunt, D., \& Bennet, G. R. (2004). Jumping and landing techniques in elite women's volleyball. Journal of Sports Science and Medicine, 3(1), 30-36.

Tokuyama, M., Ohashi, H., Iwamoto, H., Takaoka, K., \& Okubo, M. (2005). Individuality and reproducibility in high speed motion of volleyball spike jumps by phase-matching and averaging. Journal of Biomechanics, 38(10), 2050-2057.

Vaverka, F., Salinger, J., \& Novosad, J. (1979). Testování vertikálních skoků. Teorie a praxe tělesné výchovy, 27(12), 732-739.

Vaverka, F. (2000). Vertical jump - a suitable model for problems in biomechanics and motorics. In F. Vaverka \& M. Janura (Eds.), Proceedings of the conference BIOMECHANICS OF MAN 2000 (pp. 213-216). Olomouc: Univerzita Palackého.

Vint, P. F., \& Hinrich, R. N. (1996). Differences between One-Foot and Two-Foot Vertical Jump Performances. Journal of Applied Biomechanics, 12, 338-358.

Voight, H. F., \& Vetter, K. (2003). The value of strengthdiagnostics for the structure of jump training in volleyball. European Journal of Sport Science, 3(3), $1-10$.

\section{KOMPARACE EXPLOZIVNÍ ODRAZOVÉ SÍLY DOLNÍCH KONČETIN U VÝKONNOSTNĚ A VĚKOVĚ ROZDÍLNÝCH SKUPIN HRÁČEK VOLEJBALU}

(Souhrn anglického textu)

VÝCHODISKA: Sportovní výkon ve volejbalu je významně ovlivněn kvalitou odrazových schopností, především výškou skoku. Výsledky skokanských testů jsou nepř́mým indikátorem úrovně explozivní odrazové síly dolních končetin. Informace o úrovni odrazových schopností je východiskem ke kvalitnímu řízení sportovního tréninku.

CÍLE: Cílem práce je zjistit zda existují rozdíly $\mathrm{v}$ úrovni explozivní síly dolních končetin v odrazových činnostech mezi hráčkami volejbalu různého věku a výkonnostní úrovně a zda se volejbalistky liší od rekreačně sportující obecné populace žen. Vedlejším cílem bylo posoudit vhodnost aplikace tř́ testů odrazové schopnosti ve volejbalu a porovnání výsledků dvou testů vertikálních skoků.
METODA: U souboru volejbalistek $(\mathrm{n}=273)$ rozděleného do pěti rozdílných věkových a výkonnostních skupin a souboru vysokoškolských studentek $(n=33)$ byly aplikovány tř̀ testy explozivní síly dolních končetin: smečařský vertikální skok (SPJ), vertikální skok s protipohybem (CMJ) a skok daleký z místa (SBJ). Statistické metody byly aplikovány v systému Statistica CZ (Kolmogorov-Smirnov, Spearmanův koeficient korelace, párový t-test a ANOVA pro nezávislé výběry - Scheffé post-hoc test).

VÝSLEDKY: Mezi hráčkami volejbalu různého věku a výkonnostní úrovně byly zjištěny relativně malé a převážně statisticky nevýznamné diference v úrovni explozivní síly odrazu. Všechny soubory volejbalistek významně převyšovaly rekreačně sportující ženy. Výzkum naznačil nižší úroveň výsledků skokanských testů především u hráček nejvyšší výkonnostní úrovně (extra liga) než bylo očekáváno. Zkušenosti s aplikací baterie tří testů explozivní síly odrazu prokázaly jejich vhodnost pro použití ve volejbalu $\mathrm{z}$ hlediska jejich reliability a specifičnosti poskytované informace s ohledem na výkonnostní úroveň a věk testovaných hráček a rozdílné tréninkové podmínky.

ZÁVĚRY: Sledování úrovně odrazových schopností u hráčů nižší výkonnostní úrovně a mládeže pomocí exaktních metod je věnováno méně pozornosti a v této oblasti tréninku existují nedostatky. Přesná diagnostika explozivní odrazové síly by měla být východiskem pro koncipování tréninku rozvoje odrazových schopností nejen u dospělých volejbalistů, ale také u mládeže.

Klíčová slova: odrazové schopnosti, testování, vertikální skok s protipohybem, vertikální skok smečařský, volejbal, ženy.

\section{PaedDr. Zlatava Jakubšová, Ph.D.}

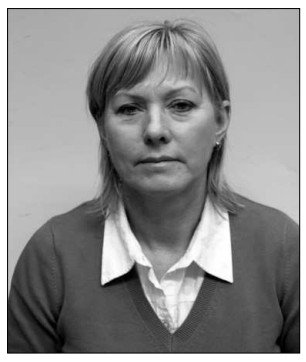

Technical University Ostrava

Department of Physical Education

17. listopadu 15

70833 Ostrava 8

Czech Republic

\section{Education and previous work experience}

1974-1979 - Faculty of Physical Education and Sport, Charles University, Prague: Master degree in Physical Education and Sports with specialization Volleyball. 1979-1982 - Children and youth building in Prague, Department of Tourism and Sport.

Since 1982 - VŠB - Technical University Ostrava, Department of Physical Education and Sport: Assistant and volleyball Trainer. 
1987 - Faculty of Physical Education and Sport, Charles University in Prague: graduated PaedDr.

2010 - Faculty of Physical Culture, Palacký University, Olomouc: Ph.D.

\section{First-line publication}

Jakubšová, Z., \& Vaverka, F. (2005). Level of explosive force of female volleyball players from 12 years adults [Abstract]. In F. Vaverka (Ed.), Movement and Health: $4^{\text {th }}$ International Conference Processing (p. 58). Olomouc: Universita Palackého.

Jakubšová, Z. (2009). Volejbalové testy. Pohyb je život, $13,3$.
Vaverka, F., Jakubšová, Z., \& Jandačka, D. (2009). The influence of extra load on time and force structure of vertical jump [Poster]. $27^{\text {th }}$ International Conference on Biomechanics in Sports, Limerick.

Vaverka, F., Jakubšová, Z., \& Jandačka, D. (2009). The influence of extra load on time and force structure of vertical jump [Abstract]. In D. Harrison, R. Anderson, \& I. Kenny (Eds.), Proceedings of the $27^{\text {th }}$ International Conference on Biomechanics in Sports (p. 629). Limerick: University of Limerick.

Jakubšová, Z. (2011). Úvod do kinantropologie pro studenty sportovního managementu. Ostrava: VŠB-TU Ostrava. 